\title{
Effect of intensive glycaemic control on fibrinogen plasma concentrations in patients with Type II diabetes mellitus. Relation with $\beta$-fibrinogen genotype
}

\author{
A. Ceriello ${ }^{1}$, F. Mercuri ${ }^{1}$, D. Fabbro ${ }^{2}$, R. Giacomello ${ }^{3}$, G. Stel ${ }^{3}$, C. Taboga ${ }^{4}$, L. Tonutti ${ }^{4}$, E. Motz $^{1}$, G. Damante ${ }^{2}$ \\ ${ }^{1}$ Department of Internal Medicine, University of Udine, Udine, Italy \\ ${ }^{2}$ Department of Science and Biomedical Technology, University of Udine, Udine, Italy \\ ${ }^{3}$ Clinical Pathology, University of Udine, Udine, Italy \\ ${ }^{4}$ Diabetology Unit, Udine General Hospital, Udine, Italy
}

\begin{abstract}
Summary Recent studies show that in diabetic subjects an increase of plasma fibrinogen concentration is associated with a high risk of cardiovascular complications. Environmental and genetic factors contribute to the plasma fibrinogen concentration. Several studies indicate a relation between the polymorphism in the $5^{\prime}$ region of the $\beta$-fibrinogen gene and plasma protein concentrations and in diabetes the possible influence of hyperglycaemia on fibrinogen is still debated. In this study we investigated these relations. Hind III polymorphism was evaluated by a polymerase chain reaction-technique. On the basis of the observed allelic combination of fibrinogen $\beta$ gene polymorphism and the existence of poor metabolic control (glycated haemoglobin $\geq 7.5 \%$ ), 50 Type II diabetic patients were selected. They were di-
\end{abstract}

vided into three groups according to their $\beta$-gene polymorphism ( $\alpha 1 \alpha 1: n=20, \alpha 1 \alpha 2: n=15, \alpha 2 \alpha 2: n=$ 15) and then intensive insulin therapy was started. After 3 months of intensive treatment, the improvement in glycaemic control was equivalent, in terms of glycated haemoglobin, in all the three groups. A fibrinogen reduction was observed in $\alpha 1 \alpha 2$ and $\alpha 2 \alpha 2$ but not in $\alpha 1 \alpha 1$ subjects. These results underline a possible relation between fibrinogen genotypes and glycaemic control in determining plasma fibrinogen concentrations in diabetic patients. [Diabetologia (1998) 41: 1270-1273]

Keywords Fibrinogen, $\beta$-fibrinogen genotype, hyperglycaemia, metabolic control, gene-enviroment interaction.
During the past decade, the potential role of haemostatic factors, particularly fibrinogen, in atherosclerosis and its complications has gained considerable interest. Since the early 1980 s, several extensive prospective observational studies have provided definite proof that fibrinogen is a powerful, independent marker for cardiovascular diseases [1]. There is also evidence that high fibrinogen plasma concentrations represent a condition of blood hypercoagulability [2, $3]$, even in diabetes [4], and that a hypercoagulable state contributes to the pathogenesis of accelerated atherosclerosis in both Type I (insulin-dependent) and Type II (non-insulin-dependent) diabetic pa-

Received: 17 April 1998 and in revised form: 14 July 1998

Corresponding author: Dr. A. Ceriello, Chair of Internal Medicine, University of Udine, P.le S. Maria della Misericordia, 33100 Udine, Italy tients [5]. In recent years a growing number of works have focused attention on fibrinogen in diabetes, confirming its role as a marker of cardiovascular risk in this disease [6]. Although hypercoagulability has been claimed to be a result rather than a cause of diabetic vascular disease, in Type I diabetic patients fibrinogen plasma concentrations have been found to be increased before the occurrence of clinically demonstrable macroangiopathy and correlated with glycaemic control [7]. Moreover, in a recent work on identical twins, an independent association between fibrinogen and diabetes has been found [8].

A number of factors influence circulating concentrations of fibrinogen, including genetic ones [9]. The three chains of fibrinogen are encoded by different genes, denoted $\alpha, \beta$ and $\gamma$, that are grouped in a cluster on the long arm of chromosome 4 [9]. The process responsible for the coordination of the expression of the three genes is poorly understood; however, the $\beta$ 
Table 1. Clinical characteristics of the diabetic patients according to $\beta$ fibrinogen genotype

\begin{tabular}{llll}
\hline & $\alpha 1 \alpha 1(n=20)$ & $\alpha 1 \alpha 2(n=15)$ & $\alpha 2 \alpha 2(n=15)$ \\
\hline Sex & 9 males-7 females & 10 males-7 females & 12 males-5 females \\
Age (years) & $59.2 \pm 1.2$ & $57.4 \pm 1.5$ & $57.9 \pm 1.4$ \\
Duration of disease & $11.4 \pm 1.0$ & $10.7 \pm 1.7$ & $11.1 \pm 1.5$ \\
BMI & $24.7 \pm 1.7$ & $25.0 \pm 1.4$ & $24.8 \pm 1.3$ \\
Smokers/non-smokers & $2 / 14$ & $1 / 16$ & $1 / 16$
\end{tabular}

Values are expressed as means \pm SEM

chain appears to have a limiting role in the production of the two other components of fibrinogen [9] and the markers of the $\beta$ fibrinogen gene showed stronger correlations with fibrinogen plasma concentrations than did those of the $\alpha$ or $\gamma$ chains [9]. Of the possible fibrinogen polymorphisms, the G-A substitution in the $5^{\prime}$ flanking region of the $\beta$-fibrinogen gene appears to be associated with the greatest differences in plasma fibrinogen concentrations [10].

The importance of a gene-environment interaction in determining fibrinogen plasma concentrations and the consequent risk of cardiovascular disease, has been affirmed frequently [11]. An important issue, notably in diabetic patients, is the relation between fibrinogen plasma concentrations and hyperglycaemia, since the studies in this area have produced conflicting results [6].The object of this study is to evaluate the possible relation between glycaemia, the $\beta$-fibrinogen gene polymorphism and fibrinogen plasma concentrations in diabetic patients.

\section{Subjects and methods}

Type II diabetic patients $(n=50)$ with poor metabolic control, treated with diet and oral hypoglycaemic agents (31 men and 19 women; aged $58.9 \pm 1.4$ years, means \pm SEM; duration of diabetes $11.0 \pm 1.3$ years, BMI $25.2 \pm 1.2$ ), were selected on the basis of the observed allelic combination $(\alpha 1 \alpha 1: n=20, \alpha 1 \alpha 2$ : $n=15, \alpha 2 \alpha 2: n=15)$ for fibrinogen $\beta$-gene polymorphism and for $\mathrm{HbA}_{1 \mathrm{c}}$ of $7.5 \%$ or more. The three groups were well matched for clinical characteristics (Table 1). None of the selected subjects had clinically symptomatic macroangiopathy as judged by pathological changes in the resting electrocardiogram, a history of cardiac angina, intermittent claudication, myocardial or cerebral infarction. None had microalbuminuria or macroalbuminuria.

This study was approved by the ethics committee of our institution. All subjects gave informed consent to the study after a detailed explanation of its experimental nature.

In all subjects fasting plasma glucose, $\mathrm{HbA}_{1 \mathrm{c}}$, fibrinogen and C-reactive protein plasma concentrations were evaluated at the start of the study. Better blood glucose control was then attempted in each patient by the use of three or four daily injections of insulin. All patients did self blood glucose monitoring and came to our unit weekly for assessment of therapy. All variables were evaluated after 3 months of improved metabolic control.

Plasma glucose was assayed by the glucose-oxidase method. $\mathrm{HbA}_{1 \mathrm{c}}$ was measured by HPLC. Plasma fibrinogen was measured by the method of Clauss [12].
Hind III fibrinogen polymorphism was evaluated by a polymerase chain reaction (PCR)-based technique [13]. From each patient $18 \mathrm{ml}$ of blood was drawn into $2 \mathrm{ml}$ of $3.8 \%$ sodium citrate. For DNA extraction, peripheral blood leucocytes were incubated overnight at $37^{\circ} \mathrm{C}$ in a digestion buffer $(100 \mathrm{mmol} / \mathrm{l}$ $\mathrm{NaCl}, 10 \mathrm{mmol} / \mathrm{l}$ tris (hydroxymethyl)amino-methane (TRIS)$\mathrm{HCl}, 25 \mathrm{mmol} / \mathrm{l} \mathrm{EDTA}, 1 \% \mathrm{SDS}$ ) containing $0.1 \mathrm{mg} / \mathrm{ml}$ of proteinase K. Nucleic acid was isolated by phenol/chloroform extraction and ethanol precipitation. Polymerase chain reaction was carried out on $100 \mu \mathrm{l}$ volume samples [8], in a Perkin Elmer-Cetus thermal cycler Norwalk-Connecticut, USA. Each sample contained $0.5 \mu \mathrm{g}$ of genomic DNA, 15 pmol of each primer $\left(5^{\prime}-3^{\prime}\right)$ : AAGAATTTGGGAATGCAATCTCTGCACCT for the coding strand of DNA and CTCCTCATTGTCGTTGACACCTTGGGAC for the noncoding strand, $100 \mu \mathrm{mol} / \mathrm{l}$ of dNTP, $10 \mathrm{mmol} / \mathrm{l}$ Tris $\mathrm{HCl} \mathrm{pH}$ $8.3,50 \mathrm{mmol} / 1 \mathrm{KCl}, 2.5 \mathrm{mmol} / 1 \mathrm{MgCl}_{2} 0.001 \%$ (weight per volume) gelatin, and $2.5 \mathrm{U}$ thermostable Taq polymerase. The solution was overlaid with $50 \mu \mathrm{l}$ of mineral oil. The initial cycle consisted of steps at $93^{\circ} \mathrm{C}$ for $3 \mathrm{~min}$, at $60^{\circ} \mathrm{C}$ for $1 \mathrm{~min}$ and at $72^{\circ} \mathrm{C}$ for $3 \mathrm{~min}$. The 30 subsequent cycles, were at $93^{\circ} \mathrm{C}$ for $1 \mathrm{~min}$, at $60^{\circ} \mathrm{C}$ for $1 \mathrm{~min}$ and at $72^{\circ} \mathrm{C}$ for $3 \mathrm{~min}$. Finally, $20 \mu \mathrm{l}$ volumes of the amplification product were digested for $4 \mathrm{~h}$ at $37^{\circ} \mathrm{C}$ with $1 \mathrm{U}$ of the HAE III restriction enzyme and the fragments fractionated by $2.5 \%$ agarose-gel electrophoresis in a $40 \mathrm{mmol} / \mathrm{l}$ Tris-Acetate buffer $\mathrm{pH} 7.7$ that contained $1 \mathrm{mmol} / \mathrm{l}$ EDTA and $0.5 \mu \mathrm{g} / \mathrm{ml}$ ethidium bromide, and made visible under UV light.

Statistical analysis was performed by matched Student's $t$-test, linear regression analysis and by analysis of variance.

\section{Results}

Basal values of fibrinogen were greater in the $\alpha 2 \alpha 2$ group $(F=16.6, p<0.001)$ but $\mathrm{HbA}_{1 \mathrm{c}}$ was not different between the groups $(F=0.4, p=\mathrm{NS})$ (Table 2). A correlation was shown between basal values of fibrinogen and $\mathrm{HbA}_{1 \mathrm{c}}$ in all the groups: $(\alpha 1 \alpha 1: r=$ $0.53, p<0.01 ; \alpha 1 \alpha 2: r=0.90, p<0.001 ; \alpha 2 \alpha 2: r=$ $0.72, p<0.002)$. This correlation remained even when the groups were pooled $(r=0.47, p<0.001)$.

After insulin therapy, an improvement of glycaemic control was observed, in terms of $\mathrm{HbA}_{1 \mathrm{c}}$ reduction, in all three groups (Table 2). The $\mathrm{HbA}_{1 \mathrm{c}}$ values observed at the end of the study were not different between the groups $(F=0.4, p=\mathrm{NS})$. A fibrinogen reduction was observed in $\alpha 1 \alpha 2$ and $\alpha 2 \alpha 2$, but not in $\alpha 1 \alpha 1$ (Table 2). At the end of the study there was no difference in fibrinogen plasma concentrations between the groups $(F=1.9, p=\mathrm{NS})$. The decrease, percentage of variation in respect to basal value, was 
Table 2. Values of fibrinogen, $\mathrm{HbA}_{1 \mathrm{c}}$ and $\mathrm{C}$ reactive protein at baseline and after 3 months of improved metabolic control in the diabetic patients grouped according to $\beta$ fibrinogen genotype

\begin{tabular}{llllllllll}
\hline & $\begin{array}{l}\text { Basal } \\
\text { fibrinogen } \\
\mathrm{g} / \mathrm{l}\end{array}$ & $p<$ & $\begin{array}{l}\text { 3-months } \\
\text { fibrinogen } \\
\mathrm{g} / \mathrm{l}\end{array}$ & $\begin{array}{l}\text { Basal } \\
\mathrm{HbA}_{1 \mathrm{c}} \\
\%\end{array}$ & $p<$ & $\begin{array}{l}3 \text {-months } \\
\mathrm{HbA}_{1 \mathrm{c}} \\
\%\end{array}$ & $\begin{array}{l}\text { Basal } \\
\text { C reactive protein } \\
\mathrm{mg} / \mathrm{L}\end{array}$ & $\begin{array}{l}p< \\
\begin{array}{l}3-\mathrm{months} \\
\mathrm{C} \text { reactive protein } \\
\mathrm{mg} / \mathrm{l}\end{array}\end{array}$ \\
\hline$\alpha 1 \alpha 1$ & $2.8 \pm 0.1$ & $\mathrm{NS}$ & $2.7 \pm 0.1$ & $8.9 \pm 0.1$ & 0.001 & $7.8 \pm 0.1$ & $3.1 \pm 0.4$ & $\mathrm{NS}$ & $3.2 \pm 0.3$ \\
$\alpha 1 \alpha 2$ & $3.3 \pm 0.1$ & 0.001 & $3.0 \pm 0.1$ & $8.7 \pm 0.3$ & 0.001 & $7.9 \pm 0.2$ & $3.5 \pm 0.8$ & $\mathrm{NS}$ & $3.3 \pm 0.6$ \\
$\alpha 2 \alpha 2$ & $3.7 \pm 0.1$ & 0.001 & $2.8 \pm 0.1$ & $8.4 \pm 0.3$ & 0.001 & $7.6 \pm 0.2$ & $3.4 \pm 0.6$ & $\mathrm{NS}$ & $3.5 \pm 0.5$ \\
\hline
\end{tabular}

Values are expressed as means \pm SEM

not detectable in the $\alpha 1 \alpha 1$ group $(-3 \pm 1.3 \%)$, intermediate in the $\alpha 1 \alpha 2$ group $(-18 \pm 5.4 \%)$, and very evident in the $\alpha 2 \alpha 2$ group $(-25 \pm 1.7 \%)$, with a difference $(F=32.4, p<0.001)$ between the groups.

A correlation was also found at that time between fibrinogen and $\mathrm{HbA}_{1 \mathrm{c}}$ in all the groups: $(\alpha 1 \alpha 1: r=$ $0.62, p<0.004 ; \alpha 1 \alpha 2: r=0.89, p<0.001 ; \alpha 2 \alpha 2: r=$ $0.51, p<0.05)$. This correlation remained even when the groups were pooled $(r=0.61, p<0.001)$.

C-reactive protein was in normal range at baseline and did not change at the end of the study (Table 2).

\section{Discussion}

In recent years fibrinogen has emerged as a predictor of cardiovascular events in diabetes [6]. Initial hyperfibrinogenaemia was associated with the subsequent occurrence of macroangiopathy and the risk of cardiovascular disease has been found to be increased in diabetic patients with high fibrinogen plasma concentrations [6].

Evidence suggests that both genetic and environmental factors concur in producing vascular complications in diabetes, and this could also be true in the particular case of fibrinogen as a cardiovascular risk factor.

Studies on the relation between fibrinogen plasma concentrations and/or certain genotypes and/or the risk of cardiovascular adverse events have had variable outcomes. Increased fibrinogen plasma concentrations were reported in normal subjects with the $\alpha 2 \alpha 2$ genotype [10], however, a relation between $\alpha 2 \alpha 2$ genotype and cardiovascular disease in non-diabetic subjects could not be established firmly [11]. In Type II diabetic patients fibrinogen $\beta$-gene polymorphism, but not fibrinogen plasma concentration, was found to be associated with cardiovascular risk [14], but in a group of subjects from a metabolic ward, including diabetic and non-diabetic patients, fibrinogen plasma concentration, but not fibrinogen $\beta$-gene polymorphism, was related to the ischaemic complications of atherosclerosis [15].

The relation between fibrinogen and hyperglycaemia is still debated, and data are not uniform. A correlation between fibrinogen and $\mathrm{HbA}_{1 \mathrm{c}}$ has been reported frequently in both diabetic and non-diabetic groups [16-20]. Moreover, $\mathrm{HbA}_{1 \mathrm{c}}$ values have been reported to be independent predictors of fibrinogen plasma concentrations in Type II diabetic patients [21] and in both Type I and Type II diabetic patients there is evidence that fibrinogen concentrations are reduced by improving glycometabolic control [6]. Conversely, such an effect could not be confirmed in Type I diabetes in the DCCT [22], nor in a recent study with Type II diabetic patients [23]. In the latter study, however, as in our results, a positive correlation between fibrinogen and $\mathrm{HbA}_{1 \mathrm{c}}$ emerged both at the beginning and at the end of the study, when $\mathrm{HbA}_{1 \mathrm{c}}$ was reduced [23].

Our data show that glycaemic control strictly influences plasma fibrinogen concentrations in diabetic patients in whom basal fibrinogen concentrations are increased, i.e. essentially those patients with $\alpha 2 \alpha 2$ genotype. These data suggest that the presence of $\alpha 2 \alpha 2$ genotype could be the factor that combines with glycaemia in determining fibrinogen plasma concentrations in diabetes. The $\alpha 1 \alpha 2$ genotype is associated with an intermediate condition between $\alpha 1 \alpha 1$ and $\alpha 2 \alpha 2$.

This finding may partly explain why previous studies produced divergent data about the influence of glycometabolic control on fibrinogen plasma concentrations in diabetes, since an undetermined proportion of subjects with the $\alpha 2 \alpha 2$ genotype in the groups recruited for those studies could have had a major influence on their outcome.

It is well known that inflammation and smoking influence fibrinogen plasma concentrations [11]. In our study these influences should be irrelevant, since Creactive protein was in the normal range at baseline and at the end of the study and only a small number of subjects were smokers, and they were uniformly distributed in the groups.

The persistent correlation between fibrinogen and $\mathrm{HbA}_{1 \mathrm{c}}$ also in diabetic patients with $\alpha 1 \alpha 1$ genotype, at baseline as well as at the end of the study, is difficult to explain. These data should be considered consistent, however, with evidence from previous studies showing the existence of that correlation in large nondiabetic groups $[16,18,20]$. Since both $\mathrm{HbA}_{1 \mathrm{c}}$ [24] and fibrinogen [1] are independent cardiovascular risk factors, even in non-diabetic people, we suggest that the interrelation between fibrinogen and glucose 
metabolism is more complex than has been thought. Studies taking into account several other factors influenced by glycometabolic control, such as lipid profile, oxidative stress or inflammation could succeed in elucidating this issue.

In conclusion, our results, showing a relation between glycaemic control and fibrinogen plasma concentrations in diabetic patients with the $\alpha 2 \alpha 2$ genotype, underscore the importance of the interaction between genetic and environmental factors in the pathogenesis of vascular diabetic complications.

\section{References}

1. Ernst E, Resch KL (1993) Fibrinogen as a cardiovascular risk factor: a meta-analysis and review of the literature. Ann Intern Med 118: 956-963

2. Ceriello A, Pirisi M, Giacomello R et al. (1994) Fibrinogen plasma concentrations as a marker of thrombin activation: new insights of the role of fibrinogen as a cardiovascular risk factor. Thromb Haemost 71: 593-595

3. Giansante C, Fiotti N, Cattin L, Da Col PG, Calabrese S (1994) Fibrinogen, D-dimer and thrombin-antithrombin complexes in a random population sample: relationships with other cardiovascular risk factors. Thromb Haemostas 71: 581-586

4. Ceriello A, Taboga C, Giacomello R et al. (1994) Fibrinogen plasma concentrations as a marker of thrombin activation in diabetes. Diabetes 43: 430-432

5. Ceriello A (1993) Coagulation activation in diabetes mellitus: the role of hyperglycaemia and therapeutic prospects. Diabetologia 36: 1119-1125

6. Ceriello A (1997) Fibrinogen and diabetes mellitus. Is it time for intervention trials? Diabetologia 40: 731-734

7. El Khawand C, Jamart J, Donckier J et al. (1993) Hemostasis variables in type I diabetic patients without demonstrable vascular complications. Diabetes Care 16: 1137-1145

8. Dubrey SW, Reaveley DR, Seed M et al. (1994) Risk factors for cardiovascular disease in IDDM: a study of identical twins. Diabetes 43: 831-835

9. Conner JM, Fowkes FGR, Wood J, Smith FB, Donnan PT, Lowe GDO (1992) Genetic variation at fibrinogen loci and plasma fibrinogen concentrations. J Med Genet 29: 480-482

10. Humphries SE (1995) Genetic regulation of fibrinogen. Eur Hearth J 16 [Suppl A]:16-20

11. Mannucci PM (1995) Recent progress in the pathophysiology of fibrinogen. Eur Hearth J 16 [Suppl A]: 25-30
12. Clauss A (1957) Gerinnungsphysiologische scnellmethode zur bestimmung der fibrinogene. Acta Haematol 17: 237-246

13. Saiki RH, Gelfand DH, Stoffel S et al. (1988) Primer-directed enzymatic amplification of DNA with a thermostable DNA polymerase. Science 239: 489-491

14. Carter AM, Mansfield MW, Stickland MH, Grant PJ (1996) $\beta$-fibrinogen gene $-455 \mathrm{G} / \mathrm{A}$ polymorphism and fibrinogen concentrations: risk factors for coronary artery disease in subjects with NIDDM. Diabetes Care 19: 1265-1268

15. Margaglione M, Di Minno G, Grandone E et al. (1995) Raised plasma fibrinogen concentrations in subjects attending a metabolic ward. Relation to family history and vascular risk factors. Thromb Haemost 73: 579-583

16. Ko GT, Yeung VT, Chan JC et al. (1997) Plasma fibrinogen concentration in a Chinese population. Atherosclerosis 131: 211-217

17. Greaves M, Malia RG, Goodfellow K et al. (1997) Fibrinogen and von Willebrand factor in IDDM: relationship to lipid vascular risk factor, blood pressure, glycaemic control and urinary albumin excretion rate: the EURODIAB IDDM Complications Study. Diabetologia 40: 698-705

18. Vitelli LL, Shahar E, Heiss G et al. (1997) Glycosylated hemoglobin concentration and carotid intimal-medial thickening in nondiabetic individuals. The Atherosclerosis Risk in Communities Study. Diabetes Care 20: 1454-1458

19. Bruno G, Cavallo-Perin P, Bargero G, Borra M, D'Errico N, Pagano G (1998) Glycaemic control and cardiovascular risk factor in Type II diabetes: a population-based study. Diabet Med 15: 304-307

20. Kayaba K, Nago N, Miyamoto T et al. (1998) Glycated hemoglobin concentrations and their correlation with atherosclerotic risk factors in a Japanese population. The Jichi Medical School Cohort Study 1993-1995. Jpn Circ J 62: 261-266

21. Bruno G, Cavallo-Perin P, Bargero G, Borra M, D'Errico N, Pagano G (1996) Association of fibrinogen with glycemic control and albumin excretion rate in patients with non-insulin-dependent diabetes mellitus. Ann Intern Med 125: 653-657

22. Mcmillan DE, Malone JI (1994) Hemorrheological effects of intensive diabetes management in the DCCT. Clin Hemorheol 14: 481-488

23. Knöbl P, Schernthaner G, Schnack C et al. (1994) Haemostatic abnormalities persist despite glycaemic improvement by insulin therapy in lean Type II diabetic patients. Thromb Haemost 71: 692-697

24. Singer DE, Natahn DM, Anderson KM, Wilson PWF, Evans JC (1992) Association of $\mathrm{HbA}_{1 \mathrm{c}}$ with prevalent cardiovascular disease in the original cohort of the Framingham Heart Study. Diabetes 41: 202-208 